\title{
ANALYSIS OF MICROPLASTIC CONTENT IN LOKAN (Geloina erosa) IN NORTH BEACH WATERS OF BENGKALIS ISLAND, RIAU PROVINCE
}

\author{
Nian Sari ${ }^{1}$, Bintal Amin ${ }^{1}$, Dessy Yoswaty ${ }^{1}$ \\ ${ }^{1}$ Department of Marine Science, Faculty of Fisheries and Marine Universitas Riau, Pekanbaru \\ * niansari0401@gmail.com
}

\begin{abstract}
The coastal waters of Pulau Bengkalis are located in the Malacca Strait and it is suspected that some of the people around the area throw away garbage and end up at sea, especially plastic waste. This research was conducted in July 2020 in the northern coastal waters of Bengkalis Island, Bengkalis Regency. The aim of this study was to analyze the type, abundance and relationship of abundance with microplastic size in Lokan soft tissue. This study uses a survey method. Data collection is primary data, data obtained during the study is presented in tables and graphs, then analyzed statistically. The results showed 3 types of microplastics, namely fibre, film and fragments. The total abundance of microplastics at station 1 was 13.199 particles/g and the total abundance at station 2 was 13.583 particles / $\mathrm{g}$. The total abundance of microplastics at the large size was 8.942 particles/g and the total abundance was higher at the small size, namely 15.774 particles/g. The results of the regression test showed that the abundance of microplastics had a weak relationship with the weight and length of the fish with a correlation coefficient between 0.21-0.40.
\end{abstract}

Keywords: Fragmen, Film, Fiber, Lokan, Kelimpahan, Pulau Bengkalis, Mikroplastik

\section{PENDAHULUAN}

Pada umumnya, proses dekomposisi plastik berlangsung sangat lambat. Diperlukan waktu hingga ratusan tahun agar plastik terdegradasi menjadi mikroplastik dan nanoplastik melalui berbagai proses fisik, kimiawi, maupun biologis. Dampak kontaminasi sampah plastik pada kehidupan di laut dipengaruhi oleh ukuran sampah tersebut. Sampah plastik yang berukuran besar, seperti benang pancing dan jaring, seringkali menyebabkan hewan-hewan terbelit. Sampah plastik yang lebih kecil, seperti tutup botol, korek api, dan pelet plastik, dapat tertelan oleh organisme perairan dan menyebabkan penyumbatan usus serta potensi keracunan bahan kimia. Sementara itu, mikroplastik dapat dicerna bahkan oleh organisme terkecil di habitat tersebut dan menimbulkan masalah di lingkungan perairan laut.

Mikroplastik merupakan jenis sampah plastik yang berukuran lebih kecil dari $5 \mathrm{~mm}$. Batas bawah ukuran partikel yang termasuk ke dalam kelompok mikroplastik belum didefinisikan secara pasti namun kebanyakan penelitian mengambil objek minimal $300 \mu \mathrm{m}$. Mikroplastik terbagi menjadi 2 kategori ukuran yaitu $(1-5 \mathrm{~mm})$ dan kecil $(<1 \mathrm{~mm})$ [1].

Berdasarkan [2], disebutkan bahwa mikroplastik ditemukan dalam seafood seperti ikan, udang, dan kerang, sedangkan pada bahan makanan lain, mikroplastik ditemukan dalam madu, beer dan garam dapur. Penelitian mengenai mikroplastik 
pada organisme laut, yang telah dilakukan di Indonesia adalah penelitian yang dilakukan oleh [3] dengan membandingkan kandungan mikroplastik pada ikan dari perairan Indonesia dan Amerika Serikat dan mendapatkan hasil bahwa sebanyak 21 sampel ikan (28\%) yang diidentifikasi dari total 76 sampel ikan yang ditangkap di perairan Indonesia ditemukan mikroplastik pada saluran pencernaannya.

Kerang lokan (Geloina erosa) merupakan kerang bivalvia yang hidup di ekosistem mangrove, khususnya pada paparan lumpur dengan ukuran dapat mencapai $11 \mathrm{~cm}^{3}$. Organisme ini banyak ditemukan di perairan Bengkalis.Kerang lokan juga banyak dikomsumsi oleh masyarakat setempat. Berdasarkan latar belakang tersebut penulis tertarik melakukan penelitian untuk menganalisis kandungan mikroplastik pada lokan (Geloina erosa) di perairan pantai Utara Pulau Bengkalis Provinsi Riau.

\section{METODE PENELITIAN Waktu dan Tempat}

Penelitian ini dilaksanakan pada bulan Juli 2020, di perairan pantai utara Pulau Bengkalis Kabupaten Bengkalis, Provinsi Riau (Gambar 1).

\section{Metode Penelitian}

Penelitian ini menggunakan metode survei. Pengumpulan data yaitu data primer berupa data yang didapat dari kegiatan survei pada 2 titik stasiun di perairan pantai utara Pulau Bengkalis dan data pengamatan dari sampel yang telah dianalisis di laboratorium.

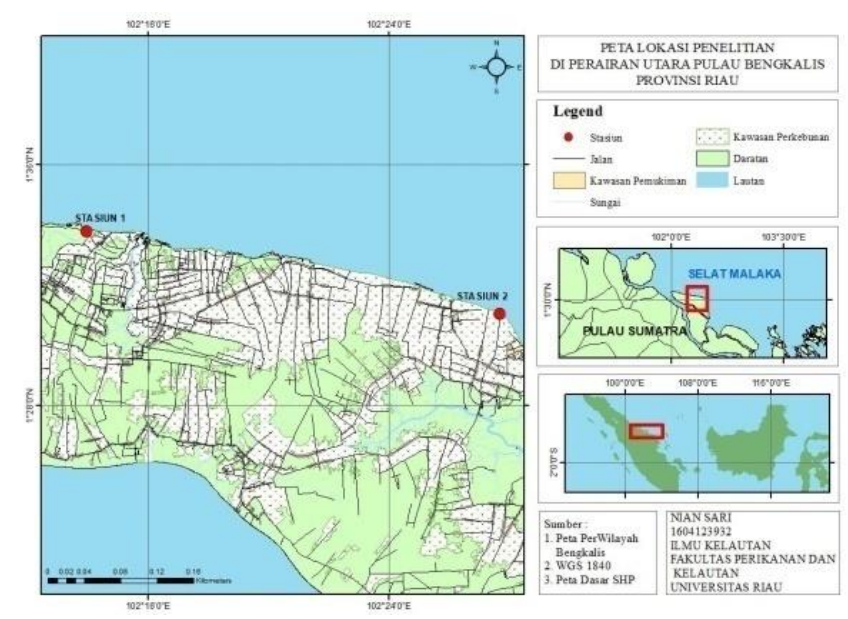

Gambar 1. Peta Stasiun Penelitian

\section{Prosedur Penelitian}

\section{Penentuan Lokasi dan Titik Sampling}

Lokasi penelitian ini ditentukan dengan cara purposive sampling atau dengan memperhatikan pertimbangan kondisi dan keadaan daerah penelitian. Lokasi pengambilan sampel dibagi atas 2 stasiun yaitu di Desa Selat Baru (stasiun 1), dan di Desa Teluk Pambang (stasiun 2).

\section{Pengambilan dan Penanganan Sampel}

Pengambilan sampel lokan dilakukan pada saat surut dari hasil tangkapan menggunakan alat bantu yaitu parang untuk mengeluarkan lokan dari lumpur. Pada sekitaran pantai utara Pulau Bengkalis sampel lokan, diambil pada setiap stasiun. Masing-masing stasiun terdapat 1 transek dengan ukuran $10 \times 10 \mathrm{~m}^{2}$. Pengambilan dilakukan secara acak yang sejajar dengan garis pantai yaitu yang berukuran kecil (6$7,5 \mathrm{~cm})$ dan yang berukuran besar (8-11 $\mathrm{cm}$ ) dan masing-masing plot kategori diambil sebanyak 1-8 individu berupa perhitungan dan dilakukan pengulangan pada jumlah sampel. Sampel diambil 
langsung di permukaan substrat yang berlumpur. Total sampel pada stasiun 1 berjumlah 16 individu dan stasiun 2 berjumlah 16 individu dengan total keseluruhan sampel pada kedua stasiun berjumlah 32 sampel. Seluruh sampel yang diambil dan disimpan pada plastik sampel 1 $\mathrm{kg}$ dan diberi larutan Formalin 10\% agar sampel tidak mengalami pembusukan selama perjalanan dan disimpan di dalam ice box.

\section{Pengukuran Parameter Kualitas Perairan}

Pengukuran parameter kualitas perairan meliputi, suhu, salinitas dan $\mathrm{pH}$. Parameter ini diukur pada saat pasang pengambilan sampel dilakukan dengan tiga kali pengulangan pada masing-masing titik sampling.

\section{Analisis Sampel Lokan}

Sampel lokan di ukur panjang cangkang nya sebelum cangkang lokan di buka untuk mengetahui berat jaringan lunak lokan menggunakan timbangan analitik, kemudian di preparasi dengan cara memasukkan setiap sampel organ jaringan lunak lokan ke dalam botol sampel yang telah diberikan larutan $\mathrm{KOH} 10 \%$ dan didiamkan selama 2 minggu [3]. Larutan $\mathrm{KOH} \quad 10 \%$ ini berfungsi untuk menghilangkan dan menghancurkan bahan organik pada sampel sehingga lebih mudah untuk mengamati.

Sampel yang sudah dilarutkan dengan larutan $\mathrm{KOH} 10 \%$ kemudian di saring menggunakan vacuum pump yang telah diberi kertas saring whattman dengan nomor 42, lalu kertas whattman diamati secara visual dibawah mikroskop Olympus CX23. Kemudian sampel mikroplastik dihitung dan digolongkan dalam beberapa jenis yakni fiber, film, fragmen dan pelet.

Pengamatan partikel mikroplastik di lakukan sebanyak 3 kali pengulangan. Setiap pengulangan pengamatan dicatat jumlah partikel mikroplastik yang ditemukan. Partikel mikroplastik yang terindentifikasi dihitung nilai kelimpahannya dengan satuan partikel/ind. Setelah itu semua alat dan peralatan dibilas tiga kali dengan air aquades untuk menghindari kontaminasi [3].

\section{HASIL DAN PEMBAHASAN}

Kondisi Umum Lokasi Penelitian

Kabupaten Bengkalis dengan Ibu Kota Bengkalis merupakan salah satu dari 11 Kabupaten/Kota di Provinsi Riau. Wilayahnya mencakup daratan bagian pesisir timur pulau Sumatra. Secara Geografis, posisi wilayah Kabupaten Bengkalis pada posisi mencakup kedalam wilayah Kabupaten Bengkalis Provinsi Riau. Wilayah ini teletak pada koordinat $2^{0} 7$ '37,2"-0 055 '33,6" LU dan $100^{0} 57^{\prime} 57,66^{\prime \prime}-102^{0} 30$ '25,2" BT. Wilayah Kabupaten Bengkalis terdiri dari pulau dan daratan serta memiliki kawasan pesisir dan laut dengan garis pantai sepanjang $446 \mathrm{~km}$ yang berbatasan dengan Desa Selat Baru (Stasiun 1), salah satu dari beberapa pantai yang ada di Pulau Bengkalis yang berada di bagian Utara Pulau Bengkalis. Pantai Selat Baru sebagai tempat wisata yang memiliki banyak pengunjung setiap harinya terutama pada saat hari libur. Selain itu terdapat sungai, pelabuhan, serta penyebrangan kapal juga terjadi di Pantai Selat Baru. Hal ini mengakibatkan sampah plastik menjadi masalah utama di daerah tersebut.

Stasiun 2 merupakan perairan Pantai di Desa Teluk Pambang, Kecamatan Bantan.Selain itu pada pantai perairan tersebut terdapat aktivitas masyarakat nelayan, perdagangan serta pengambilan remis dan kerang lokan. Pengambilan dilaksanakan pada saat surut. Pada daerah ini juga terdapat kapal-kapal nelayan dan aktivitas nelayan.

\section{Jenis dan Kelimpahan Mikroplastik berdasarkan Stasiun}


Kelimpahan mikroplastik antar stasiun berdasarkan jenis mikroplastik hanya ada tiga jenis mikroplastik yang ditemukan yaitu fiber, film, fragmen. Kelimpahan mikroplastik jenis fiber lebih tinggi ditemukan pada stasiun 1 yaitu 10,325 partikel/g lebih rendah adalah 9,305 partikel/g pada stasiun 2. Selanjutnya kelimpahan mikroplastik jenis film lebih tinggi $0,954 \mathrm{partikel} / \mathrm{g}$ ditemukan pada stasiun 1 dan lebih rendah 0,643 partikel/g ditemukan pada stasiun 2. Mikroplastik jenis fragmen lebih tinggi ditemukan pada stasiun 2 yaitu 3,635 partikel/g dan terendah adalah 1,919 partikel/g pada stasiun 1 (Gambar 1). Perbedaan kelimpahan partikel mikroplastik masingmasing penelitian disebabkan oleh karakteristik lokasi penelitian yang berbeda. Lokasi penelitian pada Desa Selat Baru dan Desa Teluk Pambang merupakan daerah pantai yang berbatasan langsung dengan Selat Malaka dan dipengaruhi oleh aktivitas perikanan (nelayan). Wilayah pesisir ini dipengaruhi oleh kegiatan antropogenik seperti pemukiman warga, wisata pantai, penyebrangan perkapalan [5].

Pengamatan jenis dan kelimpahan mikroplastik pada lokan bertujuan untuk melihat perbedaan kelimpahan terhadap mikroplastik pada biota tersebut bedasarkan lokasi yang berbeda. Kelimpahan mikroplastik pada stasiun 2 memiliki kecenderungan kelimpahan yang lebih tinggi. Hal ini diduga karena rata-rata panjang dan berat lokan pada stasiun 1 lebih besar dari pada stasiun 2. Sesuai dengan pendapat [6], bahwa ukuran panjang dan berat organisme mempengaruhi kelimpahan mikroplastik.

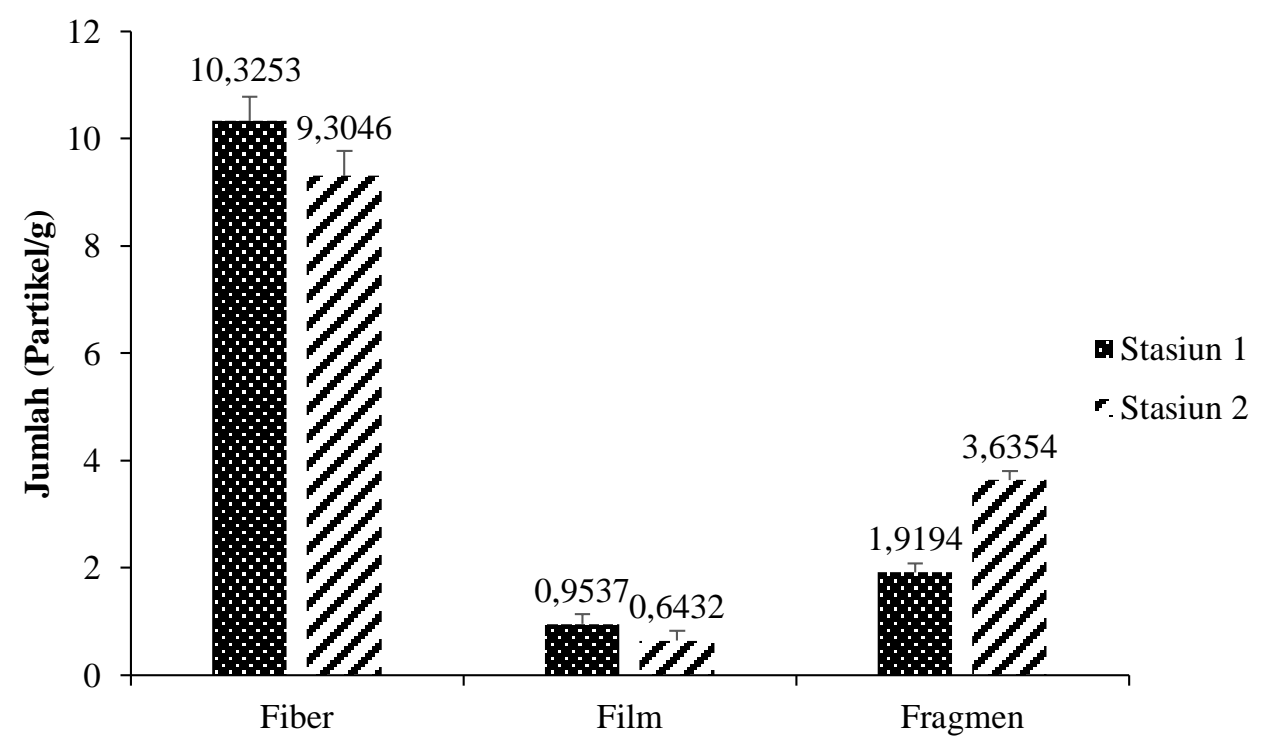

Gambar 2. Grafik Kelimpahan Mikroplastik antar Stasiun Berdasarkan Jenis

\section{Jenis dan Kelimpahan Mikroplastik berdasarkan Ukuran}

Kelimpahan total mikroplastik pada ukuran berbeda yang diamati dapat dilihat pada Tabel 2. Berdasarkan data yang tercantum pada tabel tersebut diketahui bahwa kelimpahan mikroplastik pada ukuran berbeda yang diamati menunjukkan kelimpahan total mikroplastik yang lebih rendah pada ukuran besar yakni 8,942 partikel/g, sedangkan kelimpahan total yang lebih tinggi pada ukuran kecilyakni $15,774 \mathrm{partikel/g}$.

Kelimpahan mikroplastik dibandingkan dengan hasil penelitian lainnya yang dilakukan oleh [7] rata-rata konsentrasi mikroplastik pada tubuh kerang di perairan Pulau Lae-Lae Makassar tergolong rendah 
yaitu $0,04 \pm 0,02-0,13 \pm 0,08$ fiber/g bobot basah. Konsentrasi mikroplastik di dalam tubuh kerang Mytilidae yang hidup di perairan Tiongkok berkisar antara 1,525,36 partikel/g bobot basah. Di India, [8] menemukan bahwa konsentrasi mikroplastik di dalam daging kerang hijau
Perna viridis yaitu $1,8 \pm 0,54$ partikel/g bobot basah.

Menurut [9] konsentrasi mikroplastik ikan senangin di perairan Dumai sebesar 966,67-1933,33 partikel/ind. Kelimpahan mikroplastik yang didapatkan pada setiap stasiun berdasarkan jenis dapat dilihat pada Gambar 3.

Tabel 2. Kelimpahan (Total \pm Std. deviasi) Mikroplastik Antar Ukuran Berbeda

\begin{tabular}{ccc}
\hline Ukuran & Kelimpahan (partikel/gram) & Std.deviasi \\
\cline { 1 - 3 } Kecil & 15,774 & $\pm 0,534$ \\
Besar & 8,942 & $\pm 0,289$ \\
\hline
\end{tabular}

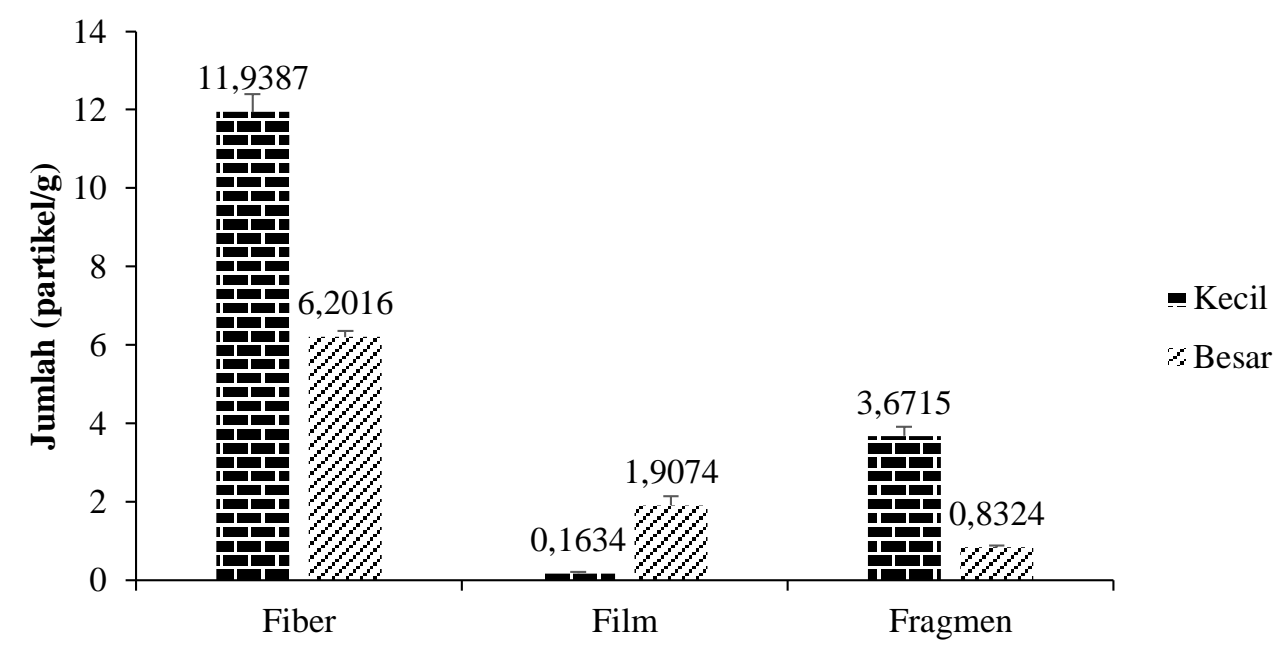

Gambar 3. Grafik Kelimpahan Mikroplastik antar Ukuran Berdasarkan Jenis

\section{Hubungan Kelimpahan Mikroplastik pada Lokan dengan Ukuran dan Panjang}

Hasil analisis regresi linier antara kelimpahan mikroplastik jenis fiber pada Lokan dengan berat yang berbeda dapat dilihat pada Gambar 4, didapatkan nilai koefesien determinansi $\mathrm{R}^{2}=0,165$ dan $\mathrm{R}=$ 0,4062 dengan persamaan regresi $\mathrm{Y}=$ $0,971+0,026 x$.

Hasil analisis regresi linier antara kelimpahan mikroplastik jenis fiber pada lokan dengan panjang tubuh yang berbeda dapat dilihat pada Gambar 5, didapatkan nilai koefesien determinansi $\mathrm{R}^{2}=0,2373$ dan $\mathrm{R}=0,4871$ dengan persamaan regresi $\mathrm{Y}=1,8059-0,1522 \mathrm{x}$.
Hasil analisis regresi linier antara kelimpahan mikroplastik jenis film pada Lokan dengan berat yang berbeda dapat dilihat pada Gambar 6, didapatkan nilai koefesien determinansi $\mathrm{R}^{2}=0,0326$ dan $\mathrm{R}$ $=0,1806$ dengan persamaan regresi $\mathrm{Y}=$ $0,0024+0,0019 x$. Hasil analisis regresi linier antara kelimpahan mikroplastik jenis film pada Lokan dengan berat yang berbeda dapat dilihat pada Gambar 7, didapatkan nilai koefesien determinansi $\mathrm{R}^{2}=0,0458$ dan $R=0,2140$ dengan persamaan regresi $Y$ $=-0,0555+0,0106 x$.

Hasil analisis regresi linier antara kelimpahan mikroplastikjenis fragmen pada lokan dengan berat yang berbeda dapat di lihat pada Gambar 8, di dapatkan nilai koefesien determinansi $\mathrm{R}^{2}=0,102$ dan $\mathrm{R}=$ 
0,3194 dengan persamaan regresi $\mathrm{Y}=$ 0,03123-0,0103x. Hasil analisis regresi linier antara kelimpahan mikroplastikjenis fragmen pada lokan dengan panjang yang

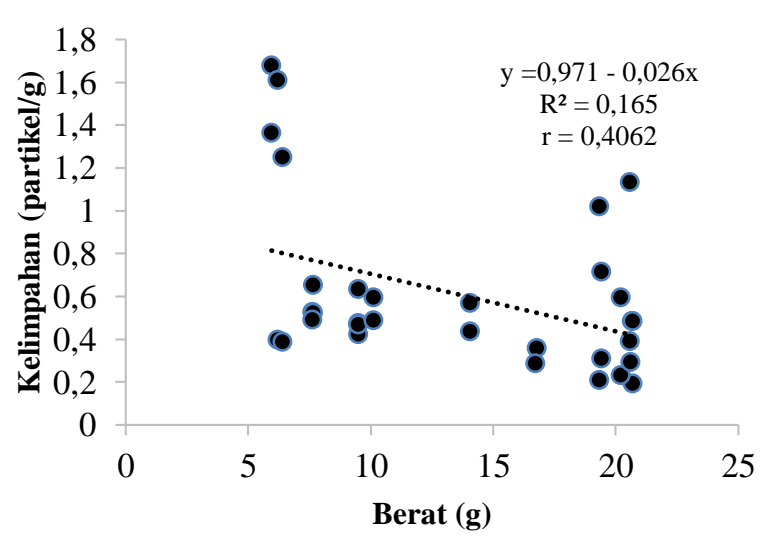

Gambar 4. Hubungan Kelimpahan Mikroplastik Jenis Fiber pada Lokan dengan Berat Tubuh

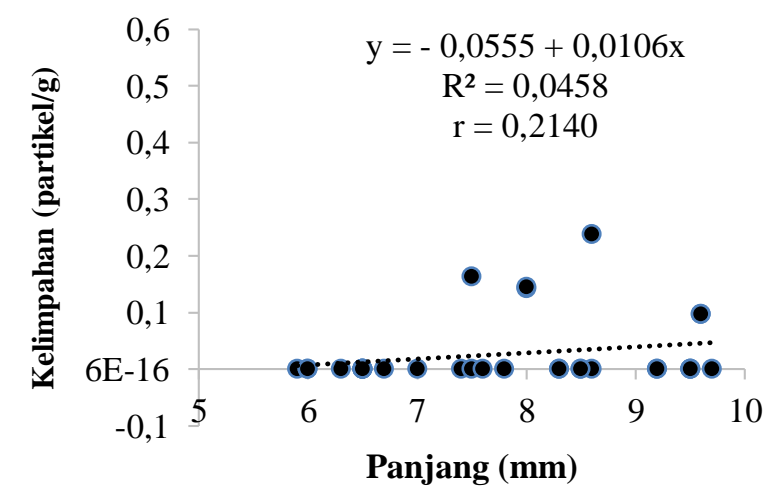

Gambar 7. Hubungan Kelimpahan Mikroplastik Jenis Film pada Lokan dengan Panjang Tubuh. berbeda dapat di lihat pada Gambar 9, di dapatkan nilai koefesien determinansi $\mathrm{R}^{2}=$ 0,1049 dan $\mathrm{R}=0,3239$ dengan persamaan regresi $Y=0,5649-0,0499 x$.

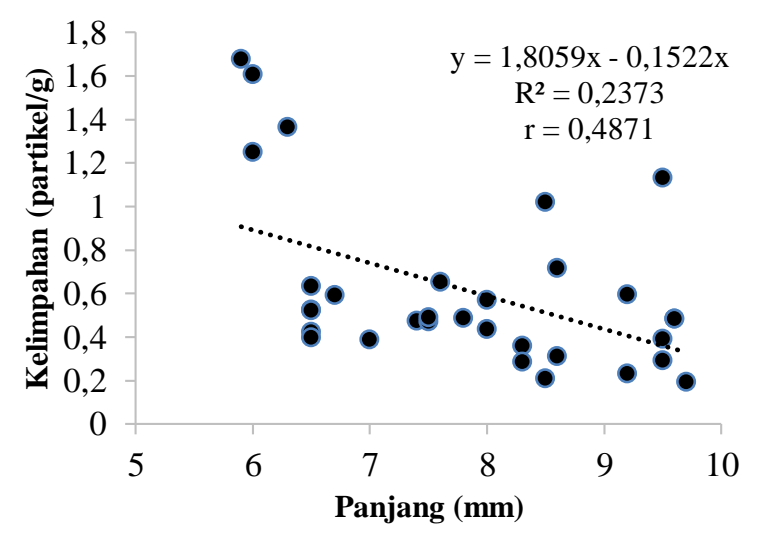

Gambar 5. Hubungan Kelimpahan Mikroplastik Jenis Fiber pada Lokan dengan Panjang Tubuh

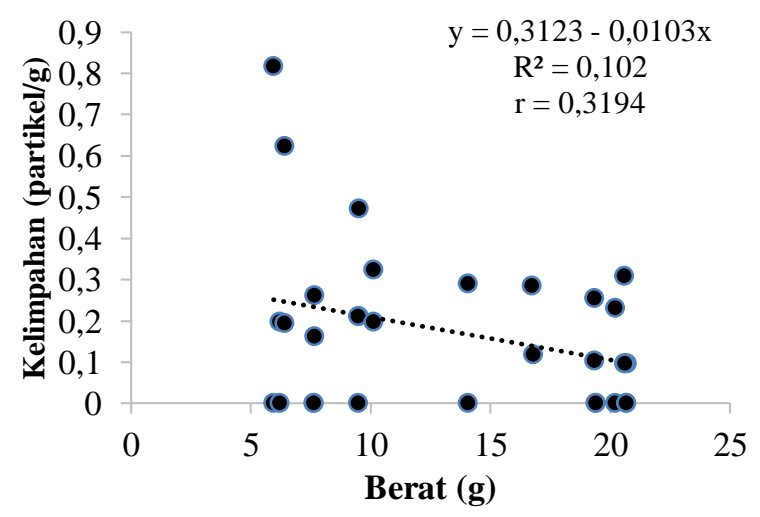

Gambar 8. Hubungan Kelimpahan Mikroplastik Jenis Fragmen pada Lokan (G.erosa) dengan Berat Tubuh.

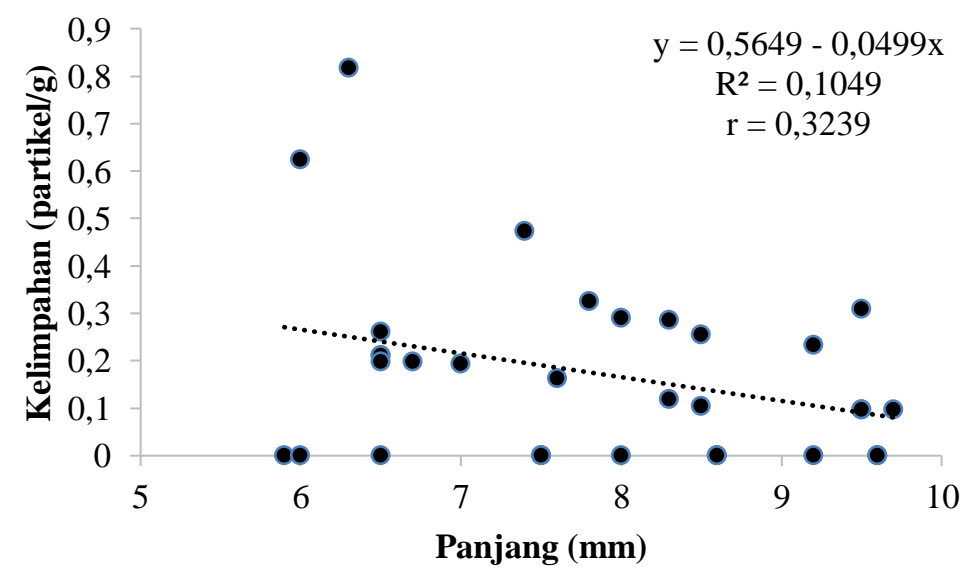

Gambar 9. Hubungan Kelimpahan Mikroplastik Jenis Fragmen pada Lokan dengan Panjang Tubuh

Berdasarkan data-data panjang cangkang dan berat daging kerang lokan dari kedua titik stasiun dengan waktu pengamatan hampir dua bulan dari bulan 
Oktober dan September didapatkan data nilai yang dipergunakan untuk menentukan hubungan antara panjang cangkang dan berat daging kerang lokan. Hubungan pada konteks ini terutama adalah seberapa besar hubungan panjang cangkang terhadap peningkatan berat daging kerang lokan, besarnya hubungan panjang cangkang dan berat daging dapat dilihat berdasarkan besarnya nilai koefisien determinasi.

Tidak jauh berbeda persamaan hubungan panjang cangkang dan berat daging kerang lokan dengan nilai koefisien kolerasi. Secara keseluruhan dengan jumlah sampel 32 diketahui bahwa nilai koefisien $b<3$ pertambahan panjang lebih dominan dari pada pertambahan berat. Hubungan antara panjang cangkang dan berat daging kerang lokan yang allometrik negatif diperkirakan terkait dengan bentuknya yang pipih dan memanjang untuk mencapai bentuk tersebut pertambahan panjang cangkang lebih cepat dibandingkan pertambahan beratnya.

Hasil perbandingan antara berat daging dan panjang cangkang dari 2 titik stasiun yaitu masing-masing ada 32 sampel kerang lokan yang diamati. Pada hubungan kelimphan mikroplastik jenis fiber pada lokan dengan berat daging dan panjang cangkang menunjukkan bahwa berkisar antara 0,4062-0,4871, hubungan kelimpahan mikroplastik jenis film pada lokan dengan berat daging dan panjang cangkang yaitu berkisar 0,1806-0,2140 sedangkan hubungan kelimpahan jenis fragmen dengan berat daging dan panjang cangkag yaitu berkisar 0,3194-0,3239. Dari hasil perbandingan didapat, kurang lebih panjang cangkang kerang lokan adalah setengah dari berat dagingnya.

Berdasarkan penelitian [10] diketahui bahwa panjang cangkang terhadap berat daging dari 900 sampel kerang hijau yang diamati menunjukkan bahwa rasio berkisar antara 0,315-0,600 dan terbagi menjadi 11 kelas dengan rasio terbanyak pada kisaran 0,445-0,47. Hubungan untuk cangkang dengan faktor lingkungan menurut penelitian [11], diketahui bahwa berdasarkan besar morfometrik cangkang kerang yang ditemukan akan berbeda sesuai dengan perbedaan faktor lingkungan tertentu.

\section{KESIMPULAN DAN SARAN}

Partikel mikroplastik yang ditemukan pada lokan berjumlah 3 jenis yaitu fiber, film, dan fragmen. Jenis fiber merupakan dengan tipe dominan dengan nilai kelimpahan total 10,325 partikel/g (Stasiun 1) dan 9,305 partikel/g (Stasiun 2), jenis fragmen yaitu 1,919 partikel/g (Stasiun 1) dan 3,635 partikel/g (Stasiun 2), dan jenis paling sedikit kelimpahan totalnya yaitu jenis fragmen dengan nilai 0,239 partikel/g (Stasiun 1) dan 0,643 partikel/g (Stasiun 2). Kelimpahan total mikroplastik pada ukuran yang berbeda yaitu 8,942 partikel/g (ukuran besar) dan 15,774 partikel/g (ukuran kecil). Kelimpahan Partikel mikroplastik yang ditemukan pada lokan di Pulau Bengkalis bernilai 13,199 partikel/g pada stasiun 1 dan 13,583 partikel/g pada stasiun 2 . Hasil uji regresi menunjukkan kelimpahan mikroplastik memiliki hubungan yang lemah dengan berat dan panjang lokan dengan nilai koefisien korelasi antara 0,21 0,40 .

Saran dari penelitian ini adalah Penelitian selanjutnya dapat dilakukan menggunakan metode, peralatan, dan objek yang lebih kompleks, serta menemukan keterkaitan antara kelimpahan mikroplastik pada biota, sedimen, air laut dan dapat menganalisis zat turunan plastik dalam daging biota serta bahaya mengkonsumsi biota yang tercemar mikroplastik. 


\section{DAFTAR PUSTAKA}

1. Tankovic, M.S., S. Perusco, V. J. Godrijan, Daniela, dan M. Pfannkuchen. (2015). Marine Plastic Debris in the Northeastern Adriatic. Procceedings of the MICRO 2015 Seminar of Microplastic Issues. Micro 2015: Book of abstracts

2. Panel, E., dan F. Chain. (2016). Presence of microplastic and nanoplastic in food, with particular focus on seafood. EFSA Journal, 14(6): 4501.

3. Rochman, C., Tahir, D.V. Baxa, S.L. William, S. Werorilangi, F.C. Teh, dan S.J. Teh. (2015). Antropogenic Debris in Seafood: Plastic Debris and Fiber from Textiles in Fish and Shellfish Sold for Human Comsumprtion. Sci.Report. 5: 14340.

4. Gimin, R., R. Mohan, L.V. Think, dan A.D. Griffiths. (2004). The Relationships of Shell Dimention and Shell Volume to Live Weight and Soft Tissue Weight in The Mangrove Clam Polymesoda erosa (Solander, 1786). Northern Australia. NAGA, Wolrld Fish Centre Quarterly. 27: 32-35.

5. Amin, B., M.Galib, dan F. Setiawan. (2020). Preliminary Investigation on the Type and Ditribution of Microplastics in the West Coast of Karimun Besar Island. Earth and Environmental Science. 430012011.

6. Jumiati. (2017). Akumulasi Logam Timbal (Pb) pada Tiram Crassostrea sp. dan Hubungannya dengan Parameter Lingkungan Laut di PerairanKecamatan Barru, Kabupaten Barru. Skripsi. Makassar. Program Studi Ilmu Kelautan Fakultas Ilmu Kelautan dan Perikanan. Universitas Hasanuddin Makassar

7. Qu, X., L. Su, H. Li, M. Liang, dan H. Shi. (2018). Assessing the relationship between the abundance and properties of microplastics in water and in mussels. Science of the total environment, 621:679-686.

8. Dowarah, K., A. Patchaiyappan, C.T. Vukkarasu, S. Jayakumar, dan S.P. Devipriya. (2020). Quantification of microplastics using Nile Red in two bivalve species Perna viridis and Meretrix meretrix from three estuaries in Pondicherry, India and microplastic uptake by local communities through bivalve diet. Marine Pollution Bulletin. 153:1-9.

9. Mirad, A., D. Yoswaty, dan Thamrin. (2020). Identification Microplastic Waste in Seawater and the Digestive Organs of Senangin Fish (E. tetradactylum) at Dumai City Seawater. Asian Journal of Aquatic Sciences, 3(3): 248-259

10. Prihartini, D. (2006). Estimasi umur optimum kerang hijau (Perna viridis. 1) yang dibudidayakan di muara Kamal, Teluk Jakarta. Skripsi. Bogor:Institut Pertanian Bogor.

11. Aisyah, N.S., M. Affandi, dan B. Irawan. (2011). Karakteristik morfologis cangkang kerang air tawar (Unionidae) di sungai Brantas. Universitas Airlangga: Surabaya. 